JURNAL KETAHANAN NASIONAL

Vol. 24, No.2, Agustus 2018, Hal 215-238

DOI:http://dx.doi.org/ 10.22146/jkn.35367

ISSN:0853-9340(Print), ISSN:2527-9688(Online)

Online sejak 28 Desember 2015 di :http://jurnal.ugm.ac.id/JKN

VOLUME 24

No. 2, Agustus 2018

Halaman 215-238

\title{
Studi Komparasi Praktik Perladangan Berpindah Dan Pertanian Menetap Untuk Mendukung Ketahanan Pangan Masyarakat (Studi Pada Usahatani Kentang di Kabupaten Pegunungan Arfak, Provinsi Papua Barat)
}

\author{
Umi Yuminarti \\ Fakultas Pertanian Universitas Papua \\ email: yuminartiumi@ymail.com
}

\section{Dwidjono Hadi Darwanto}

Fakultas Pertanian Universitas Gadjah Mada email: dwidjonohd@hotmail.com

\section{Jamhari}

Fakultas Pertanian Universitas Gadjah Mada email: jamhari@ugm.ac.id

\section{Subejo}

Fakultas Pertanian Universitas Gadjah Mada email: subejo@ugm.ac.id

\begin{abstract}
This study examined the shifting cultivation farming and settled farming by Arfak farmers, and their implications on the community food resilience. The research was conducted in Minyememut and Arion Villages at Hink District, and Suteibey and Igymbai Villages at Anggi District of Arfak Mountains Regency of West Papua Province. The objective of the study wass to compared potato farming, productivity and farmer income from potato farming.

The research used analytical descriptive method, and in-depth interviews techniques for data collection, by using questionnaires, field observation and documentation. Data analysis was done by tabulation analysis, data interpretation and conclusion withdrawal.

The results showed that potato farming was still done by using shifting cultivation system. However, there had been a settled farming practice in Arfak Mountains Regency. Although the system used was different, but the two of the agricultural practices were still using the same technology. Potato farms' area of shifting cultivation was larger than the settled farming, so the production was greater. On the other hand, the productivity of settled farming was higher than the shifting cultivation system. This condition showed that the shifting cultivation farming and settled farming had implications for supporting community food security in Arfak Regency.
\end{abstract}

Keywords: Potato Farming, Shifting Cultivation, Settled Farming, Community Food Resilience

\begin{abstract}
ABSTRAK
Penelitian ini mengkaji usahatani kentang perladangan berpindah dan usahatani menetap yang dilakukan petani Arfak dan implikasinya pada ketahanan pangan masyarakat. Penelitian ini dilakukan di kampung Minyememut
\end{abstract}


dan Arion Distrik Hink, dan kampung Suteibey dan Igymbai Distrik Anggi Kabupaten Pegunungan Arfak Provinsi Papua Barat. Tujuan penelitian adalah melakukan komparasi usahatani kentang, produktivitas dan pendapatan petani dari usahatani kentang.

Metode dalam penelitian ini adalah diskriptif analitis, dan teknik pengumpulan data dengan wawancara mendalam menggunakan kuisioner, observasi lapang dan dokumentasi. Analisis data dilakukan dengan analisis tabulasi, interpretasi data serta penarikan kesimpulan.

Hasil penelitian menunjukkan bahwa usahatani kentang masih dilakukan dengan cara perladangan berpindah, namun telah ada yang mempraktekkan secara menetap di Kabupaten Pegunungan Arfak. Meskipun sistem yang digunakan berbeda, tetapi kedua praktek pertanian tersebut masih menggunakan teknologi sama. Lahan tanaman kentang pada perladangan berpindah lebih luas, sehingga produksi lebih banyak. Namun produktivitas lahan usahatani menetap lebih tinggi dibanding perladangan berpindah dan secara statistik terdapat perbedaan. Sedangkan pendapatan yang diperoleh petani tidak terdapat perbedaan. Keadaan ini menunjukkan usahatani kentang perladangan berpindah dan usahatani menetap berimplikasi mendukung ketahanan pangan masyarakat di Kabupaten Pegunungan Arfak.

Keywords: Usahatani Kentang, Perladangan Berpindah, Usahatani Menetap, Ketahanan Pangan Masyarakat

\section{PENGANTAR}

Indonesia berada di wilayah dengan iklim tropis, kondisi ini sangat menguntungkan untuk pengembangan tanaman pertanian, karena tanaman pangan, hortikultura dan tanaman perkebunan dapat tumbuh dengan baik. Menurut data Atlas Tata Ruang Pertanian, Indonesia memiliki luas daratan sekitar 188,20 juta ha, dimana 148 juta ha (78\%) merupakan lahan kering dan 40,20 juta ha (22\%) lahan basah. Kenyataan yang terjadi tidak seluruh lahan kering sesuai untuk pertanian, karena adanya faktor pembatas seperti lereng yang sangat curam atau solum tanah dangkal dan berbatu. Praktik pertanian pada lahan kering dengan kondisi lereng, solum tanah dangkal dan berbatu sebagian besar dilakukan oleh petani perladangan berpindah. Kondisi ini secara tidak langsung untuk memenuhi kecukupan dan stabilitas ketersediaan bahan pangan sebagai komponen yang harus dipenuhi dalam mencapai kondisi ketahanan pangan sebagaimana yang diamanatkan UU RI. No.7 Tahun 1996 tentang Pangan.

Perladangan berpindah (shifting cultivation) merupakan suatu sistem pertanian lahan kering, umumnya di daerah tropis yang dilakukan berdasarkan pengalaman masyarakat secara turun temurun dalam mengolah lahan. Berbagai penelitian menghasilkan pandangan negatif dan positif tentang perladangan berpindah. Pandangan negatif menyebutkan perladangan berpindah menyebabkan penggundulan hutan dan erosi tanah. Pernyataan lain yang terekspose bahwa kebakaran hutan di berbagai daerah disebabkan adanya sistem perladangan berpindah. Menurut Houghton, dkk (1991), sistem ladang berpindah ini juga disalahkan karena hilangnya 10 persen kawasan hutan di Amerika. Pendapat yang sama dinyatakan oleh Serrao, dkk (1996) bahwa 30 persen sampai 35 persen dari hutan di Amazon hilang karena perladangan berpindah. Demikian pula menurut Jong (2001), luas lahan pada sistem perladangan berpindah disalahkan atas hilangnya 50 persen kawasan hutan di Indonesia. Selain itu, produktivitas perladangan berpindah juga dianggap sangat rendah dan boros sumber daya, bila dibandingkan dengan risiko lingkungan yang akan terjadi.

Pandangan positif tentang perladangan berpindah menyebutkan bahwa, meskipun perladangan berpindah tidak dapat diharapkan lebih ramah lingkungan dibandingkan hutan alam, namun perladangan berpindah memberikan keadaan yang lebih baik terhadap lingkungan daripada sistem pertanian yang 
Umi Yuminarti, Dwidjono Hadi Darwanto, Jamhari, Subejo -- Studi Komparasi Praktik Perladangan Berpindah dan Pertanian Menetap untuk Mendukung Ketahanan Pangan Masyarakat (Studi pada Usahatani Kentang di Kabupaten Pegunungan Arfak, Provinsi Papua Barat)

lebih intensif lainnya. Hal ini disebabkan sampah hutan dan sisa tanaman, serta dengan gangguan tanah minimal dalam sistem perladangan berpindah, dapat membentuk lapisan penutup tanah secara terus menerus yang melindungi tanah dari erosi.

Pertanian perladangan berpindah pada umumnya dilakukan oleh masyarakat tradisional pada suatu daerah dengan tingkat kepadatan penduduk rendah. Semakin berkembang suatu wilayah dan semakin banyak jumlah penduduk, artinya tingkat kepadatan semakin tinggi sistem ini tidak dapat diterapkan. Hal ini sebagai faktor penyebab masyarakat petani merasa perlu mulai menerapkan sistem usahatani menetap, sehingga pemanfaatan lahan usahatani menjadi lebih efisien, dan menghindarkan dari pembukaan hutan primer. Berdasarkan data BPS Tahun 2016, tingkat kepadatan penduduk Kabupaten Pegunungan Arfak 10,19 jiwa/ $\mathrm{km} 2$. Kondisi ini yang menyebabkan pertanian perladangan berpindah masih dilakukan petani suku Arfak. Namun sejak wilayah pegunungan Arfak menjadi kabupaten baru pada tahun 2012, petani pada beberapa wilayah di sekitar ibukota kabupaten mulai menerapkan pertanian secara menetap, sebagai akibat pertumbuhan penduduk di sekitar terutama penduduk pendatang yang mencari peluang memperoleh pekerjaan di wilayah baru.

Kentang berpotensi sebagai komoditi potensial di Kabupaten Pegunungan Arfak mengingat kabupaten ini terletak di wilayah yang sesuai dengan syarat tumbuh untuk usahatani kentang. Kentang berfungsi sebagai tanaman pangan selain ubi-ubian bagi masyarakat, dan sejak dahulu diusahakan dengan sistem perladangan berpindah yang dilakukan secara turun temurun. Namun sekarang usahatani kentang pada beberapa wilayah telah dilakukan dengan sistem pertanian menetap. Produksi kentang sejak tahun 2009 hingga saat ini mengalami penurunan tajam, hal ini diduga peralihan pola makan dari ubi-ubian ke beras, sebagai akibat bantuan beras dari pemerintah melalui program Raskin sejak tahun 1998. Walapun produksi kentang menurun tetapi, ubi-ubian sebagai bahan pangan lokal lain membantu tetap tersedianya pangan, selain itu hasil kentang yang dijual digunakan kembali untuk membeli bahan pangan, sehingga ketahanan pangan tetap terjaga.

Saat ini beras telah dinikmati oleh masyarakat, tetapi petani tetap mengusahakan kentang dan ubi-ubian terutama ubi jalar untuk dikonsumsi sebagai makanan pokok. Khusus untuk komoditi kentang, produksinya selain dikonsumsi juga dijual untuk memenuhi kebutuhan pangan dan non pangan keluarga, sehingga kebutuhan pangan masyarakat Kabupaten Pegunungan Arfak terpenuhi baik melalui produk pangan lokal ubi-ubian yang sebagian besar dikonsumsi dan dan kentang yang saat ini sebagian besar dijual. Hal ini sesuai dengan konsep ketahanan pangan berdasarkan UU RI No. 7 Tahun 1996 yang menyatakan bahwa ketahanan pangan adalah terpenuhinya kebutuhan pangan bagi rumah tangga, yang tercermin dari tersedianya pangan secara cukup, baik jumlah maupun mutunya, aman merata dan terjangkau. Dalam hal ini hasil usahatani kentang digunakan sebagai bahan pangan yang dapat disediakan rumah tangga petani ketika beras dari program Raskin (Beras untuk Rumah Tangga Miskin) pemerintah belum tersedia di kampung. Di sisi lain produksi kentang bukan hanya sebagai bahan pangan pokok yang dikonsumsi oleh petani dan keluarganya, namun kentang juga sebagai produk komersial sebagai sumber pendapatan petani. Selanjutnya 
pendapatan dari hasil penjualan kentang dapat dimanfaatkan untuk membeli beras dan bahan pangan lainnya untuk memenuhi kebutuhan keluarga, mengingat anak-anak dan generasi muda di Kabupaten Pegunungan Arfak telah terbiasa mengkonsumsi nasi sebagai pengganti ubi-ubian.

Penelitian ini lebih mengarahkan kajian tentang produksi dan produktivitas, dan pendapatan yang diperoleh dari usahatani kentang pada ladang berpindah maupun pada usahatani menetap, sehingga masyarakat di Kabupaten Pegunungan Arfak dapat menyediakan kebutuhan pangannya. Komoditi kentang meskipun produksinya menurun, namun dipilih sebagai komoditi yang menjadi fokus penelitian. Hal ini disebabkan kentang merupakan komoditi potensial di Kabupaten Pegunungan Arfak dan memiliki nilai ekonomi, tetapi belum di tangani secara serius. Untuk itu tujuan dari penelitian ini adalah mengkomparasi usahatani kentang pada kedua sistem usahatani tersebut. Hasil penelitian diharapkan menjadi dasar apakah perlu transformasi pertanian ladang berpindah menjadi pertanian menetap untuk mendukung ketahanan pangan.

Beberapa teori yang dipergunakan untuk mendasari penelitian ini dijelaskan sebagai berikut.

Pertama, teori usahatani. Usahatani adalah sebagian dari kegiatan di permukaan bumi dimana seorang petani, sebuah keluarga atau manajer yang digaji bercocok tanam atau memelihara ternak. Apa yang dilakukan petani ini hanya sekedar memenuhi kebutuhan, dalam arti petani meluangkan waktu, uang dalam mengkombinasikan masukan untuk menciptakan keluaran adalah usahatani yang dipandang sebagai suatu jenis perusahaan (Soekartawi, 2002).
Soehardjo dan Dahlan Patong (1993), mengemukakan bahwa usahatani sebagai objek pengamatan dapat dilihat dari empat segi, yaitu menurut bentuk, tipe, corak dan pola usahatani. Berdasarkan tipenya usahatani menunjukkan klasifikasikasi tanaman yang didasarkan pada macam dan cara penyusunan tanaman. Dalam pola tanam atau penyusunan tanaman maka usahatani dapat dibedakan menjadi usahatani monokultur dan usahatani campuran.

Dalam pengelolaan usahatani yang efisien perlu memperhatikan biaya dan penerimaan dari proses produksi, agar usahatani tersebut mendatangkan pendapatan bagi petani. Besar biaya produksi akan bergantung pada output yang dihasilkan, sementara ada beberapa biaya yang tetap harus dikeluarkan pada berbagai tingkat output yang dihasilkan. Oleh karena itu Pindyck \& Rubinfeld (2001) membagi biaya produksi menjadi dua komponen, yaitu biaya tidak tetap (variable cost) dan biaya tetap (fix cost). Penerimaan usahatani merupakan perkalian antara produksi dan harga jual yang diperoleh petani(Soekartawi, 2002). Penerimaan ini merupakan penerimaan kotor yang diperoleh petani dari penjualan hasil produksi usahatani, yang dirumuskan sebagai berikut:

$$
T R=\sum_{i=1}^{n} Y \cdot P_{x}
$$

Dimana: $\mathrm{TR}=$ total penerimaan kotor, $\mathrm{Y}=$ jumlah produksi, $\mathrm{Px}=$ harga produksi.

Selisih antara penerimaan kotor dan semua biaya yang dikeluarkan untuk usahatani disebut dengan keuntungan usahatani, dengan rumus sebagai berikut:

$$
\pi=T R-T C .
$$

Dimana: $\pi \pi=$ keuntungan, $\mathrm{TR}=$ penerimaan kotor, $\mathrm{TC}=$ biaya total. 
Umi Yuminarti, Dwidjono Hadi Darwanto, Jamhari, Subejo -- Studi Komparasi Praktik Perladangan Berpindah dan Pertanian Menetap untuk Mendukung Ketahanan Pangan Masyarakat (Studi pada Usahatani Kentang di Kabupaten Pegunungan Arfak, Provinsi Papua Barat)

Menurut Crammer, dkk (1994) berdasarkan rumus tersebut akan dihasilkan keuntungan ekonomi (pure profit), dengan kondisi penerimaan usahatani lebih besar dari jumlah biaya eksplisit dan implisit produksi. Konsep keuntungan ini selanjutnya disebut dengan keuntungan normal (normal profits) karena setiap sumber daya usahatani yang digunakan pada saat proses produksi dinilai sebagai biaya peluang (opportunity cost).

Pengertian pendapatan menurut Soekartawi (1986), adalah penerimaan yang telah dikurangi dengan biaya yang secara riil dikeluarkan petani. Indikator keberhasilan suatu usahatani dilihat dari sudut ekonomi adalah dari besarnya pendapatan yang diperoleh dari selisih pendapatan kotor dan pengeluaran total usahatani. Pendapatan kotor (gross farm income) merupakan nilai produk total usahatani dalam jangka waktu tertentu yang mencakup nilai produk yang dijual, produk yang dikonsumsi, produk untuk pembayaran, dan produk untuk disimpan. Sedangkan pengeluaran total usahatani (total farm expenses) adalah semua pengeluaran tidak tetap (variable cost) dan pengeluaran tetap (fixed cost) yang mencakup pengeluaran tunai maupun tidak tunai tetapi tidak termasuk tenaga kerja keluarga. Pendapatan usahatani yang besar memungkinkan petani dapat mengembangkan usahanya.

Menurut Anderson dan Griffiths (1982), persamaan pendapatan usahatani adalah sebagai berikut:

$$
\mathrm{I}=\mathrm{P}_{\mathrm{y}} \cdot \mathrm{Y}-\sum_{i=1}^{n} P_{x i} X_{\mathrm{i}} \sum_{i=1}^{n} P_{x i} X_{\mathrm{i}}
$$

Dimana: $\mathrm{I}=$ pendapatan usahatani, $\mathrm{Py}=$ harga produksi, $\mathrm{Y}=$ produksi, $\mathrm{Pxi}=$ harga faktor produksi ke-I, dan $\mathrm{X}_{\mathrm{i}}=$ faktor produksi ke $\mathrm{i}$

Boediono (1997) mengungkapkan bahwa jumlah pendapatan usahatani mempunyai fungsi untuk memenuhi keperluan seharihari dan memberikan kepuasan kepada petani agar dapat melanjutkan produksinya. Usahatani komersial selalu berorientasi memaksimalkan pendapatan, sedangkan usahatani semi subsisten lebih mengutamakan kepuasan atau kegunaan bagi keluarganya, sehingga pendapatan bersih yang diterima petani baik dalam bentuk tunai maupun tidak tunai merupakan ukuran pendapatan usahatani (Soekartawi, dkk, 1986). Sesuai dengan pendapat Brown (1979), bahwa dalam menghitung pendapatan untuk petani semisubsisten adalah dengan mengurangkan total biaya variabel usahataninya dari nilai jual, kecuali nilai tenaga kerja keluarga (gross margin).

Kedua, teori produksi dan produktivitas. Definisi produksi secara umum adalah penciptaan barang dan jasa untuk memenuhi kebutuhan manusia, dan dalam proses produksi terdapat penambahan utility pada barang dan jasa yang dihasilkan. Menurut Beattie dan Taylor (1985) produksi adalah hasil kombinasi dan koordinasi beberapa material dan beberapa kekuatan (berupa input, faktor, sumber daya atau jasa produksi) untuk menciptakan suatu barang atau jasa (output atau produk). Sedangkan menurut Mubyarto (1994), produksi adalah hal yang diperoleh sebagai akibat bekerjanya faktor produksi tanah, modal, dan tenaga kerja secara simultan.

Produktivitas adalah perbandingan antara output dengan input atau jumlah output per unit input. Produktivitas dapat digunakan sebagai ukuran keragaan relatif dari perbedaan antar industri, perusahaan atau perekonomian (Jamison and Lau, 1982; Samuelson and Nordhaus, 2001). Dalam proses produksi pertanian, lahan merupakan salah satu input yang penting sehingga produktivitas lahan 
sering digunakan sebagai ukuran keragaan suatu usahatani, sehingga produktivitas lahan adalah jumlah output per unit luas lahan. Pengertian produktivitas secara teknis adalah pengefisiensian produksi terutama dalam pemakaian ilmu dan teknologi. Produktivitas dapat ditingkatkan dengan cara menurunkan input dan meningkatkan output.

Konsep dasar yang digunakan untuk analisis produktivitas adalah fungsi produksi (Jamison and Lau, 1982). Dengan demikian faktor-faktor yang mempengaruhi produktivitas sama dengan faktor-faktor yang mempengaruhi produksi. Faktor produksi yang merupakan komponen input dalam usahatani adalah tanah, tenaga kerja, modal, manajemen, energi, informasi dan sebagainya yang turut berperan sebagai bahan baku produk.

Produktivitas sebagai jumlah output untuk setiap unit input dapat dirumuskan sebagai berikut:

$$
\text { Produktivitas }=\frac{\text { output }}{\text { input }}
$$

Ketiga, teori ketahanan pangan. Ketahanan pangan berdasarkan Undangundang No.7 Tahun 1996 tentang Pangan adalah, kondisi terpenuhinya pangan bagi setiap rumah tangga yang tercermin dari tersedianya pangan yang cukup, baik jumlah maupun mutunya, aman, merata, dan terjangkau. Ketahanan pangan memiliki tiga pilar menurut World Health Organization (WHO), yaitu ketersediaan pangan, aksesibilitas pangan, dan pemanfaatan pangan (utilitas). Yang dimaksud dengan ketersediaan pangan adalah kemampuan seseorang untuk memiliki sejumlah pangan yang cukup untuk kebutuhan dasarnya, sedangkan aksesibilitas adalah cara seseorang memperoleh bahan pangan, dan utilitas pangan adalah kemampuan seseorang memanfaatkan bahan pangan yang berkualitas (Hakim 2014).

Berdasarkan hasil Musyawarah Pembangunan Pertanian, kegiatan pembangunan pertanian periode 2005-2009 dilaksanakan melalui tiga program, yaitu (1). Program peningkatan ketahanan pangan, (2). Program pengembangan agribisnis, dan (3). Program peningkatan kesejahteraan petani. Menurut Darwanto (2005), program ketahanan pangan tersebut diarahkan pada kemadirian masyarakat/petani yang berbasis sumberdaya lokal yang secara operasional dilakukan melalui program peningkatan pangan. Namun pada kenyataannya program tersebut belum sepenuhnya terlepas dari beras sebagai komoditi basis strategis. Selanjutnya dengan semakin berkurangnya areal garapan per petani, keterbatasan pasokan air irigasi dan mahalnya harga input serta relatif rendahnya harga produk, menjadi faktorfaktor pembatas/kendala program peningkatan kesejahteraan dan kemandirian petani yang berbasis sumberdaya lokal tersebut, khususnya produk beras. Berbeda dengan pendapat Arifin (2005), yang menyatakan bahwa ketahanan pangan merupakan tantangan untuk mencapai kesejahteraan bangsa pada abad milenium ini, dimana menurut PP 68/2002 ketahanan pangan harus bertumpu pada sumberdaya pangan lokal yang mengandung keragaman antar daerah. Dalam hal ini dapat dikatakan bahwa produk beras bukan menjadi basis strategis karena ketahanan pangan dapat bertumpu pada sumberdaya lokal seperti misalnya ubi-ubian, sagu bahkan kentang.

Dalam pembahasan masalah ketahanan pangan hal terpenting adalah akses pangan, yaitu kemampuan rumah tangga untuk memperoleh cukup pangan, baik yang berasal dari produksi sendiri, membeli, barter, hadiah, 
Umi Yuminarti, Dwidjono Hadi Darwanto, Jamhari, Subejo -- Studi Komparasi Praktik Perladangan Berpindah dan Pertanian Menetap untuk Mendukung Ketahanan Pangan Masyarakat (Studi pada Usahatani Kentang di Kabupaten Pegunungan Arfak, Provinsi Papua Barat)

pinjaman dan bantuan pangan maupun kombinasi kelimanya (Dewan Ketahanan Pangan, 2009). Dengan demikian pengertian ketahanan pangan tidak hanya mencakup ketersediaan pangan yang cukup, tetapi juga kemampuan untuk mengakses, yaitu termasuk membeli kebutuhan pangan, serta tidak adanya ketergantungan pangan dari pihak manapun. Ini berarti petani dalam ketahanan pangan memiliki kedudukan strategis sebagai produsen, juga sebagai konsumen yang sebagian besar tergolong miskin, dan memiliki daya beli rendah terhadap produk pangan. Untuk dapat mengakses pangan petani harus memiliki kemampuan memproduksi pangan, dan menjual hasil produksi sehingga memiliki pendapatan yang cukup untuk memnuhi kebutuhannya.

Metode penelitian yang digunakan dalam penelitian ini adalah metode survey dengan menggunakan analisis deskriptif analitis. Penentuan sampel distrik dan kampung dengan menggunakan metode purposive sampling (Nasir, 2005). Sebagai lokasi praktik pertanian perladangan berpindah dipilih Distrik Hink pada Kampung Minyeimemut dan Kampung Arion berdasarkan pertimbangan, petani pada distrik tersebut sebagian besar masih melakukan praktik perladangan berpindah. Lokasi pertanian menetap dipilih Distrik Anggi pada Kampung Suteibey dan Kampung Igmbay, karena sebagian besar petani telah menerapkan praktik pertanian menetap.

Untuk kepentingan analisis data, pengambilan data petani kentang sistem ladang berpindah dan menetap dilakukan secara sensus. Pada pertanian menetap di Distrik Hink sebanyak 51 petani, terdiri 29 petani dari Kampung Minyeimemut dan 22 petani dari Kampung Arion, sedangkan pada pertanian menetap di Distrik Anggi sebanyak
53 petani, terdiri 28 petani dari Kampung Suteibey dan 25 petani dari Kampung Igmbay. Untuk membandingkan pendapatan, dan produktivitas pertanian ladang berpindah dan menetap dengan menganalisis lebih dahulu produksi, pendapatan, dan produktivitas, dimana produksi adalah jumlah kentang yang dihasilkan per musim tanam, diukur dalam satuan kilogram per musim ( $\mathrm{kg} / \mathrm{musim})$. Pendapatan diukur dengan penerimaan dikurangi biaya produksi, dalam satuan ( $\mathrm{Rp} /$ musim), sedangkan produktivitas adalah rasio produksi dengan luas lahan diukur melalui produksi per luas lahan dalam satuan $\mathrm{kg} / \mathrm{ha}$ atau ton/ha.

\section{PEMBAHASAN}

\section{Profil Kabupaten Pegunungan Arfak}

Kabupaten Pegunungan Arfak merupakan salah satu kabupaten di Provinsi Papua Barat yang terletak pada koordinat $133^{\circ} 15^{\prime} 33^{\prime \prime}$ - 13407'30" Bujur Timur dan 0106'38" - 01036'57' Lintang Selatan. Secara administratif Kabupaten Pegunungan Arfak, sebelah Utara berbatasan dengan Kabupaten Manokwari, di sebelah Timur berbatasan dengan Kabupaten Manokwari Selatan, di sebelah Barat Kabupaten Manokwari dan Kabupaten Tambrauw, dan di sebelah Selatan Kabupaten Teluk Bintuni dan Kabupaten Manokwari Selatan.

1 Kabupaten Pegunungan Arfak terbentuk pada tahun 2012, setelah terpisah dari Kabupaten Manokwari sebagai kabupaten induk. Kabupaten ini memiliki 10 distrik dengan luas wilayah $3.468 \mathrm{~km}^{2}$. Distrik Hink sebagai lokasi perladangan berpindah memiliki luas wilayah 434,506 $\mathrm{km}^{2}$ terdiri dari 29 kampung, sedangkan Distrik Anggi sebagai lokasi usahatani menetap dengan luas $326,226 \mathrm{~km}^{2}$ memiliki 13 kampung. Lokasi 
Gambar 1

Lokasi Penelitian Pada Wilayah Administratif Kabupaten Pegunungan Arfak

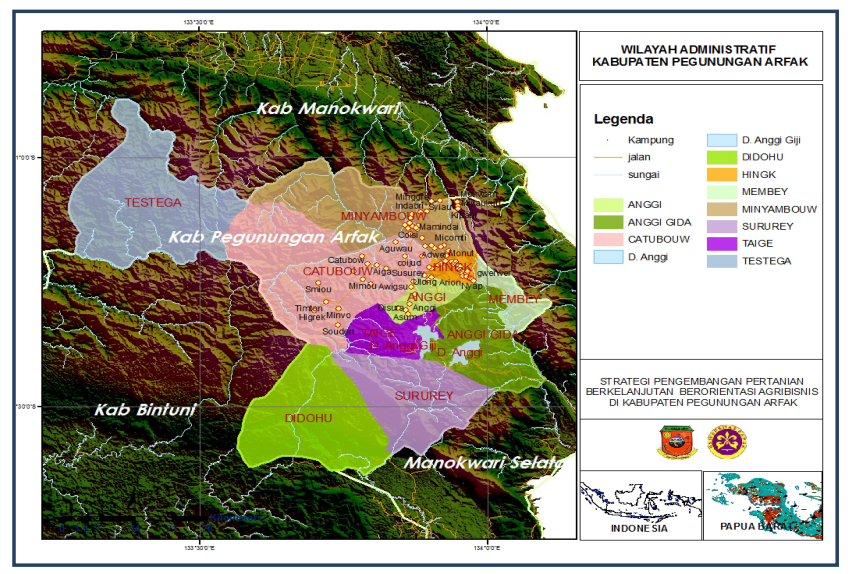

Sumber : Laporan Pengembangan Pertanian Tanaman Pangan, Perkebunan, Peternakan, Kehutanan Dan Perikanan Berorientasi Agribisnis Di Kabupaten Pegunungan Arfak, 2015

penelitian di wilayah administratif Kabupaten Pegunungan Arfak disajikan pada gambar 1.

Topografi Kabupaten Pegunungan Arfak meliputi daerah pegunungan, rawa, perbukitan sampai gunung. Wilayah datar dengan kemiringan dua sampai tiga persen berupa daerah rawa dengan kemiringan dua persen seluas $21 \mathrm{~km}^{2}(0,6 \%)$ dari total luas kabupaten. Kondisi ini menyebabkan berbagai kegiatan usahatani masyarakat Arfak harus menyesuaikan dengan keadaan wilayah tersebut untuk menjaga ketahanan pangan masyarakat, dan kelestarian daerah pegunungan.
Kabupaten Pegunungan Arfak memiliki gunung tertinggi di Papua Barat yaitu Gunung Umsini, dengan ketinggian mencapai 2.950 m dpl. Secara keseluruhan Kabupaten Pegunungan Arfak berada pada ketinggian antara 155 meter hingga 2.950 meter di atas permukaan laut (dpl). Lokasi usahatani menetap terdapat di Kampung Suteibey maupun Igmbay di Distrik Anggi berada pada ketinggian $700 \mathrm{~m}$ dpl. Sedangkan perladangan berpindah di Kampung Minyememut dan Kampung Arion Distrik Hink masing-masing berada pada ketinggian $1.300 \mathrm{~m}$ dpl dan

Tabel 1

Penggunaan Lahan Di Kabupaten Pegunungan Arfak

\begin{tabular}{lcc}
\hline \multicolumn{1}{c}{ Penggunaan Lahan } & Luas (Ha) & Persentase (\%) \\
\hline Danau dan Sungai & $4.626,4$ & 1,34 \\
Lahan Kering Tidak Produktif & $28.490,6$ & 8,27 \\
Hutan Dataran Rendah & $285.969,1$ & 83,02 \\
Hutan Dataran Tinggi & $2.045,9$ & 0,59 \\
Pertanian Lahan Kering + Semak & $2.028,2$ & 0,59 \\
Pemukiman dan kebun & $2.611,3$ & 0,76 \\
Tanah Terbuka & $18.703,4$ & 5,43 \\
\hline Jumlah & 344.474 .9 & 100,00 \\
\hline
\end{tabular}

Sumber : Laporan Pengembangan Pertanian Tanaman Pangan, Perkebunan, Peternakan Kehutanan dan Perikanan yang berorientasi Agribisnis di Kabupaten Pegunungan Arfak, 2015 
Umi Yuminarti, Dwidjono Hadi Darwanto, Jamhari, Subejo -- Studi Komparasi Praktik Perladangan Berpindah dan Pertanian Menetap untuk Mendukung Ketahanan Pangan Masyarakat (Studi pada Usahatani Kentang di

Kabupaten Pegunungan Arfak, Provinsi Papua Barat)

Tabel 2

Luas Tata Guna Hutan Kesepakatan Di Wilayah Pegunungan Arfak

\begin{tabular}{lcc}
\hline \multicolumn{1}{c}{ Jenis Pemanfaatan } & Luas (ha) & Persentase (\%) \\
\hline Hutan Lindung & $177,411.0$ & 51.6 \\
Cagar Alam Darat & $82,873.4$ & 24.1 \\
Hutan Produksi Terbatas & $57,904.5$ & 16.8 \\
Areal Penggunaan Lain & $20,886.6$ & 6.1 \\
Hutan Produksi & $2,691.0$ & 0.8 \\
Danau & $2,260.4$ & 0.7 \\
\hline Jumlah & $344,026.9$ & 100.0 \\
\hline
\end{tabular}

Sumber : Data BPS Provinsi Papua Barat 2016

$2.030 \mathrm{~m}$ dpl. Letak kedua distrik pada dataran tinggi ini merupakan faktor pendukung untuk pertumbuhan tanaman hortikultura, khususnya kentang yang menjadi komoditi potensial di wilayah ini.

Karakteristik penggunaan lahan di Kabupaten Pegunungan Arfak sebagian besar $(83,02 \%)$ adalah hutan dataran rendah, Penggunaan lahan untuk permukiman dan kebun tercatat sangat kecil $(0,76 \%)$, karena petani sebagian besar membuka lahan untuk usahatani sesuai dengan kebutuhannya, walaupun lahan yang tersedia untuk usahatani masih luas. Penggunaan lahan di Kabupaten Pegunungan Arfak disajikan pada tabel 1.

Penggunaan lahan menurut tata guna hutan kesepakatan (Dinas Kehutanan Provinsi Irian Jaya, 1994) di wilayah Pegunungan Arfak meliputi hutan lindung, cagar alam darat, hutan produksi terbatas, areal penggunaan lain, hutan produksi dan danau. Tata guna hutan kesepakatan di Wilayah Pegunungan Arfak disajikan pada tabel 2.

Berdasarkan tabel 2 diketahui bahwa sebagian besar hutan di Kabupaten Pegunungan Arfak diperuntukkan sebagai hutan lindung dan kawasan konservasi. Hal ini berarti keberadaan wilayah pegunungan Arfak memiliki fungsi sebagai penyangga lingkungan, sehingga wilayah dataran rendah disekitarnya seperti Kabupaten Manokwari, Kabupaten Manokwari Selatan terhindar dari bencana terkena dampak erosi dan kerusakan lingkungan.

Jumlah penduduk di Kabupaten Pegunungan Arfak adalah 26.729 jiwa yang terdiri dari 13.284 laki-laki dan 13.445 perempuan (BPS Provinsi Papua Barat, 2014) tersebar pada 10 Distrik di Kabupaten Pegunungan Arfak. Data penduduk setelah kabupaten ini terbentuk hingga tahun 2016 belum dipublikasikan oleh kantor BPS Kabupaten Pegunungan Arfak. Penduduk di Kabupaten Pegunungan Arfak sebagian besar merupakan penduduk yang memiliki aksesibilitas tinggi. Jumlah penduduk yang tercatat berdasarkan kenyataan di lapangan dan ditemui tidak sebanyak data yang tersaji karena banyak penduduk yang tidak selalu berada di tempat tinggalnya atau tidak menetap. Hal ini disebabkan penduduk pada umumnya melakukan aktifitas sehari-hari di distrik lain di wilayah Kabupaten Pegunungan Arfak atau bahkan di distrik lain di wilayah Kabupaten Manokwari.

Sarana dan prasarana yang terdapat di Kabupaten Pegunungan Arfak merupakan penunjang kegiatan masyarakat, antara lain sarana pendidikan, perekonomian, transportasi serta keadaan pertanian di wilayah 
ini secara berturut-turut disajikan pada uraian berikut. Tentu saja ketersediaan sarana dan prasarana transportasi yang semakin baik akan mempengaruhi peningkatan kondisi pendidikan dan perekonomian masyarakat.

Tingkat pendidikan yang baik di suatu wilayah tidak terlepas dengan ketersediaan sarana dan prasarana pendidikan yang dimiliki wilayah tersebut. Pendidikan yang baik dapat berpengaruh terhadap kondisi sosial ekonomi masyarakat. Adapun sarana dan prasarana pendidikan di Kabupaten Pegunungan Arfak disajikan pada tabel 3.

\section{Tabel 3}

Jumlah Sekolah dan Jumlah Guru di Kabupaten Pegunungan Arfak Tahun 2015

\begin{tabular}{lrr}
\hline $\begin{array}{c}\text { Tingkat } \\
\text { Pendidikan }\end{array}$ & $\begin{array}{c}\text { Jumlah Sekolah } \\
\text { (unit) }\end{array}$ & \multicolumn{2}{c}{$\begin{array}{c}\text { Jumlah Guru } \\
\text { (orang) }\end{array}$} \\
\hline SD & 55 & 271 \\
SLTP & 11 & 106 \\
SLTA & 3 & 33 \\
SMK & 1 & 6 \\
\hline Jumlah & 70 & 416 \\
\hline
\end{tabular}

Sumber : Badan Pusat Statistik Provinsi Papua Barat, 2016

Tabel 3 menunjukkan bahwa selain tingkat perguruan tinggi seluruh jenjang pendidikan telah tersedia di Kabupaten Pegunungan Arfak, namun demikian sebagian besar sarana pendidikan tersebut berada di ibu kota kabupaten. Sekolah yang terdapat disetiap distrik hanya tingkat SD dan SLTP. Jumlah SLTA dan SMK yang terbatas di Kabupaten Pegunungan Arfak menyebabkan penduduk usia sekolah pada tingkatan tersebut pada umumnya melanjutkan pendidikan di kabupaten lainnya atau di ibu kota Provinsi Papua Barat.

Sarana perekonomian di Kabupaten Pegunungan Arfak berupa toko, kios/warung yang menyediakan kebutuhan sehari-hari masyarakat, serta pasar sebagai pusat kegiatan tukar menukar uang dengan barang terutama hasil pertanian. Jumlah pasar dan toko masing-masing hanya 1 (satu) terletak di ibu kota kabupaten. Pasar hanya dibuka tiga kali selama satu minggu. Sebagian besar petani di wilayah ini menjual hasil pertaniannya di Manokwari sebagai ibu kota Provinsi Papua Barat. Sarana produksi seperti bibit, dan obatobatan untuk memenuhi kebutuhan input pertanian dibeli petani dari toko di ibu kota provinsi, karena toko atau kios di ibu kota kabupaten tidak menyediakan input produksi pertanian.

Alat transportasi yang dapat digunakan menuju kabupaten Pegunungan Arfak dari ibu kota Provinsi sangat terbatas, hal ini disebabkan sebagian besar kondisi jalan baru tahap pengerasan dengan topografi bergunung dan medan yang sulit dilalui oleh kendaraan roda dua dan roda 4 standart. Kondisi ini menyebabkan biaya transportasi dari ibu kota provinsi ke berbagai wilayah kabupaten Pegunungan Arfak mencapai Rp. 300.000,sampai Rp. 500.000,- (pp). Saat ini angkutan darat ke berbagai distrik di kabupaten ini telah meningkat, namun angkutan udara yang telah ada sejak kabupaten ini belum terbentuk tetap melayani penerbangan dari Manokwari (Ibu kota provinsi Papua Barat) menuju Anggi (Ibu kota Kabupaten Pegunungan Arfak).

Kabupaten Pegunungan Arfak sebagai salah satu kabupaten di Provinsi Papua Barat memiliki potensi sebagai daerah penghasil sayuran dataran tinggi yang dapat mensuplai kebutuhan penduduk di Papua Barat. Berbagai jenis tanaman, baik tanaman pangan dan hortikultura sebagian besar diusahakan pada ladang berpindah yang masih dilakukan oleh masyarakat di kabupaten ini. Jenis tanaman pangan yang diusahakan adalah ubi jalar dan 
Umi Yuminarti, Dwidjono Hadi Darwanto, Jamhari, Subejo -- Studi Komparasi Praktik Perladangan Berpindah dan Pertanian Menetap untuk Mendukung Ketahanan Pangan Masyarakat (Studi pada Usahatani Kentang di

Kabupaten Pegunungan Arfak, Provinsi Papua Barat)

Tabel 4

Produksi Tanaman Pangan dan Sayuran di Kabupaten Pegunungan Arfak

\begin{tabular}{lccc}
\hline \multicolumn{1}{c}{ Jenis Tanaman } & Luas Panen (ha) & Produksi (ton) & Produktivitas (kw/ha) \\
\hline Ubi Jalar & 127 & 1651 & 734,64 \\
Ubi Kayu & 152 & 1599,3 & 721,4 \\
Keladi & 78 & 710 & 654,0 \\
Jagung & 109 & 165,2 & 109,6 \\
\hline
\end{tabular}

Sumber: Laporan Pengembangan Agribisnis Hortikultura Dataran Tinggi Pegunungan Arfak Kabupaten Manokwari, 2012

Tabel 5

Data Luas Panen, Produksi dan Produktivitas tanaman Kentang di Provinsi Papua Barat Tahun 2009-2013

\begin{tabular}{cccc}
\hline Tahun & Luas Panen $(\mathrm{Ha})$ & Produksi (Ton) & Produktivitas (Ton/Ha) \\
\hline 2009 & 121 & 378 & 3.12 \\
2010 & 86 & 256 & 2.98 \\
2011 & 78 & 170 & 2.18 \\
2012 & 14 & 98 & 7,00 \\
2013 & 3 & 23 & 7.70 \\
\hline
\end{tabular}

Sumber : BPS Provinsi Papua Barat, 2014 (diolah)

keladi/talas dan jagung, sedangkan kentang sebagai tanaman hortikultura oleh masyarakat suku Arfak dimanfaatkan sebagai tanaman pangan pengganti ubi jalar. Tanaman lainnya yang banyak diusahakan adalah wortel, kol, sawi, buncis dan daun bawang. Luas panen produksi dan produktivitas tanaman pangan di Kabupaten Pegunungan Arfak diuraikan pada tabel 4.

Pada tabel 4 tampak bahwa, produksi tanaman pangan terbesar adalah ubi jalar, hal ini disebabkan ubi jalar sebagai makanan pokok masyarakat suku Arfak di daerah pegunungan Arfak, selain itu ubi jalar pada panen terakhir umumnya digunakan untuk makanan ternak babi dengan cara memasukkan babi dalam kebun berpagar hingga sisa-sisa ubi jalar di dalam kebun habis. Ternak babi yang memakan sisa hasil panen juga difungsikan sebagai kegiatan pengolahan tanah. Kegiatan yang sama juga dilakukan petani yang telah menerapkan praktik usahatani menetap.

Produksi kentang dari tahun ke tahun di Kabupaten Pegunungan Arfak sebelum dan setelah menjadi kabupaten menunjukkan penurunan dari waktu ke waktu. Penurunan produksi disebabkan masyarakat tidak lagi bergantung pada kentang sebagai makanan pokok setelah ada bantuan beras dari pemerintah (Raskin). Selain itu faktor lain penyebab penurunan produksi kentang adalah gangguan serangan hama yang menyebabkan petani sering mengalami gagal panen, sehingga menyebabkan petani enggan menanam kentang. Luas panen, produksi dan produktivitas kentang disajikan pada tabel 5 .

Tabel 5 menunjukkan bahwa, pada tahun 2009-2013 luas panen dan produksi kentang mengalami penurunan, namun produktivitas cenderung mengalami peningkatan. Peningkatan produktivitas tercapai pada tahun 2012 dan 2013. Faktor penyebab luas panen semakin menurun tetapi produktifitasnya meningkat adalah, pada petani dengan usahatani menetap melakukan cara memperpendek jarak tanam kentang, sehingga pemanfaatan lahan menjadi lebih efisien. Sementara pada petani yang melakukan 
Tabel 6

Umur Petani Perladangan Berpindah Dan Usahatani Menetap Di Kabupaten Pegunungan Arfak

\begin{tabular}{lrrrr}
\hline Umur (Th) & Ladang Berpindah (orang) & Persentase (\%) & Usahatani Menetap (orang) & Persentase $(\%)$ \\
\hline $15-25$ & 25 & 49,02 & 8 & 15,09 \\
$26-35$ & 13 & 25,49 & 25 & 47,17 \\
$36-45$ & 6 & 11,76 & 11 & 20,75 \\
$46-55$ & 5 & 9,80 & 8 & 15,09 \\
$>65$ & 2 & 3,92 & 1 & 1,89 \\
\hline Jumlah & 51 & 100,00 & 53 & 100,00 \\
\hline
\end{tabular}

Sumber : Data primer, 2017

usahatani kentang pada ladang berpindah tentu saja mengusahakan kentang pada lahan yang baru dibuka sehingga menghasilkan kentang dengan produksi lebih tinggi.

Luas panen yang menurun pada tahun 2009 sampai tahun 2013 mencapai -97,52\%, hal ini disebabkan banyaknya penduduk usia muda yang memiliki pendidikan setara SLTA lebih tertarik bekerja sebagai tenaga honorer pada instansi-instansi pemerintah yang baru terbentuk di Kabupaten Pegunungan Arfak dari pada sebagai petani. Hal ini berakibat tenaga kerja yang benar-benar bekerja penuh pada usahatani dilakukan oleh anggota keluarga lainnya atau istri yang berpendidikan rendah atau tidak berpendidikan. Dengan tenaga kerja terbatas maka kemampuan untuk membuka lahan usahatani juga terbatas. Penurunan luas panen, berpengaruh terhadap berkurangnya jumlah tenaga kerja dalam usahatani, sehingga menyebabkan penurunan produksi hingga mencapai $-93,92 \%$.

\section{Karakteristik Sosial Ekonomi Petani Perladangan Berpindah dan Usahatani Menetap}

Petani suku Arfak yang mengusahakan perladangan berpindah sebanyak 51 petani berasal dari sub suku Hatam, sebagian besar $(88,35 \%)$ berjenis kelamin laki-laki dan sisanya berjenis kelamin perempuan. Sedangkan pada usahatani menetap jumlah petani sebanyak 53 petani, dan sebanyak 73,58 persen berjenis kelamin laki-laki. Karakteristik lain seperti tingkat umur, pendidikan, jumlah anggota keluarga dan pengalaman petani perladangan berpindah dan petani dengan usahatani menetap disajikan pada tabel-tabel berikut. Karakteristik petani pada praktik pertanian ladang berpindah dan menetap menurut umur disajikan pada tabel 6 .

Tabel 6 menunjukkan bahwa, jumlah petani perladangan berpindah sebagian besar lebih muda jika dibandingkan dengan petani pada usahatani menetap, namun demikian petani pada praktik pertanian tersebut sebagian besar masih berada pada usia produktif, kondisi ini memungkinkan petani masih dapat melakukan kegiatan usahatani dengan baik, karena tenaga kerja yang berusia muda memiliki tenaga lebih kuat dibanding jika banyak petani berusia tua.

Pendidikan petani pada kedua sistem usahatani secara keseluruhan tergolong rendah, karena persentase terbesar $(37,25 \%)$ petani perladangan berpindah dan $28,30 \%$ petani dengan usahatani menetap tidak sekolah. Sebaran tingkat pendidikan petani perladangan berpindah dan petani dengan usahatani menetap disajikan pada tabel 7 .

Berdasar tabel 7 diketahui bahwa sebagian besar petani perladangan berpindah dan usahatani menetap tidak sekolah. Hal ini disebabkan petani pada masa usia sekolah akses pendidikan 
Umi Yuminarti, Dwidjono Hadi Darwanto, Jamhari, Subejo -- Studi Komparasi Praktik Perladangan Berpindah dan Pertanian Menetap untuk Mendukung Ketahanan Pangan Masyarakat (Studi pada Usahatani Kentang di

Kabupaten Pegunungan Arfak, Provinsi Papua Barat)

Tabel 7

Sebaran Tingkat Pendidikan Petani Perladangan Berpindah Dan Usahatani Menetap

Di Kabupaten Pegunungan Arfak

\begin{tabular}{lcccc}
\hline Tingkat Pendidikan & Ladang Berpindah (orang) & Persentase (\%) & Usahatani Menetap (orang) & Persentase (\%) \\
\hline Tidak Sekolah & 19 & 37,25 & 15 & 28,30 \\
SD & 10 & 19,61 & 14 & 26,42 \\
SMP & 7 & 13,73 & 8 & 15,09 \\
SLTP & 11 & 21,57 & 8 & 15,09 \\
SLTA & 4 & 7,84 & 8 & 15,09 \\
\hline Jumlah & 51 & 100,00 & 53 & 100,00 \\
\hline
\end{tabular}

Sumber : Data primer, 2017

Tabel 8

Jumlah Anggota Keluarga Petani Perladangan Berpindah Dan Usahatani Menetap Di Kabupaten Pegunungan Arfak

\begin{tabular}{lcccc}
\hline Jumlah Anggota Keluarga & $\begin{array}{c}\text { Ladang Berpindah } \\
\text { (jiwa) }\end{array}$ & $\begin{array}{c}\text { Persentase } \\
(\%)\end{array}$ & $\begin{array}{c}\text { Usahatani Menetap } \\
\text { (orang) }\end{array}$ & $\begin{array}{c}\text { Persentase } \\
(\%)\end{array}$ \\
\hline $1-3$ & 26 & 50,98 & 22 & 41,51 \\
$4-6$ & 22 & 43,14 & 27 & 50,94 \\
$>6$ & 3 & 5,88 & 4 & 7,55 \\
\hline Jumlah & 51 & 100,00 & 53 & 100,00 \\
\hline
\end{tabular}

Sumber : Data primer, 2017

Tabel 9

Pengalaman Petani Perladangan Berpindah Dan Usahatani Menetap Di Kabupaten Pegunungan Arfak

\begin{tabular}{lcccc}
\hline Pengalaman (Th) & Ladang Berpindah (orang) & Persentase (\%) & Usahatani Menetap (orang) & Persentase $(\%)$ \\
\hline $1-5$ & 6 & 11,76 & 1 & 1,88 \\
$6-10$ & 19 & 37,26 & 12 & 23,00 \\
$11-15$ & 11 & 21,57 & 18 & 33,92 \\
$>15$ & 15 & 26,41 & 22 & 41,20 \\
\hline Jumlah & 51 & 100,00 & 53 & 100,00 \\
\hline
\end{tabular}

Sumber : Data primer, 2017

masyarakat di wilayah pegunungan Arfak masih sulit terjangkau. Sebagian petani yang memiliki pendidikan lebih tinggi menempuh pendidikan di Kota Manokwari.

Jumlah Anggota keluarga merupakan modal dalam usahatani, banyaknya penduduk berusia muda di Kabupaten Pegunungan Arfak menggambarkan keadaan anggota keluarga pada petani perladangan berpindah dan usahatani menetap. Sebaran jumlah angota keluarga petani disajikan pada tabel 8 .

Sebagian besar jumlah anggota keluarga petani perladangan berpindah lebih sedikit dari pada jumlah anggota keluarga pada usahatani menetap. Faktor penyebab jumlah anggota keluarga lebih rendah pada perladangan berpindah karena, sebagian besar petani merupakan keluarga muda atau banyak petani membentuk keluarga baru.

Pengalaman petani dalam usahataninya sangat penting dalam kegiatan pertanian, petani dengan pengalaman lebih banyak cenderung memiliki kemampuan lebih banyak dalam kegiatan berusahatani dibanding petani dengan pengalaman lebih sedikit. Sehingga pengalaman juga akan mempengaruhi produksi pertanian. Sebaran pengalaman petani dalam berusahani kentang disajikan pada tabel 9 . 
Tabel 10

Sebaran Petani Berdasarkan Luas Kebun Kentang Pada Perladangan Berpindah Dan Usahatani Menetap Di Kabupaten Pegunungan Arfak

\begin{tabular}{lcccc}
\hline Luas Kebun (ha) & Ladang Berpindah (orang) & Persentase (\%) & Usahatani Menetap (orang) & Persentase (\%) \\
\hline$<0,05$ & 2 & 3,92 & 23 & 43,39 \\
$0,05-0,10$ & 10 & 19,61 & 26 & 49.06 \\
$0,11-0,15$ & 20 & 39,22 & 3 & 5.66 \\
$0,16-0,20$ & 9 & 17,64 & 1 & 1.89 \\
$>0,2$ & 10 & 19,61 & - & - \\
\hline Jumlah & 51 & 100,00 & 53 & 100,00 \\
\hline
\end{tabular}

Sumber : Data primer, 2017

Pada tabel 9 tampak bahwa petani perladangan berpindah dan usahatani menetap memiliki pengalaman yang cukup dalam berusahatani kentang, sebagian besar memiliki pengalaman lebih dari 5 tahun. Dengan pengalaman yang telah cukup banyak membantu petani dalam memahami cara berusahatani kentang, serta dalam menyelesaikan permasalahan yang dihadapi dalam usahatani. Jumlah anggota keluarga cukup besar, dengan pengalaman yang cukup dan dengan rata-rata umur petani yang masih produktif merupakan kondisi yang menguntungkan bagi petani karena merupakan sumber tenaga kerja sebagai aset untuk keberlanjutan usahataninya.

Kepemilikan lahan kebun dan pola tanam pada petani ladang berpindah dan pertanian menetap berdasarkan jumlah dan luas kebun petani disajikan pada tabel 10 .

Pada tabel 10 ditunjukkan bahwa petani kentang pada perladangan berpindah memiliki lahan usahatani kentang lebih luas, dimana terdapat $19,61 \%$ petani yang memiliki luas lahan lebih dari 0,2 hektar, sedangkan pada usahatani menetap tidak terdapat petani yang memiliki luasan lahan tersebut. Hal ini disebabkan luas lahan perladangan berpindah cukup besar, sehingga petani lebih mempunyai kesempatan untuk membuka lahan lebih luas dibanding petani pada usahatani menetap.
Lahan keluarga pada suku Arfak merupakan lahan komunal, namun setiap keluarga mempunyai areal yang menjadi hak dan tanggungjawab sesuai dengan ketentuan dari tetua adat dalam klan. Sebagian besar kebun yang menjadi hak suatu keluarga digunakan secara bersama oleh seluruh keluarga dalam satu klan, sehingga dapat terjadi satu keluarga memiliki lebih dari satu lokasi kebun.

Lokasi Distrik Hink yang terletak pada ketinggian menyebabkan perladangan berpindah berada di lereng-lereng pegunungan. Petani melakukan kegiatan bercocok tanam tanpa menggunakan teknik pengolahan lahan, dimana penanaman dilakukan sesuai dengan kondisi kemiringan lahan yang cukup curam. Lahan pada kondisi tersebut mempengaruhi cepat hilangnya kesuburan tanah. Keadaan tersebut sebagai penyebab sebagian besar petani menggunakan lahannya kurang lebih selama 2 tahun atau 3 kali penanaman kentang.

Kentang seringkali ditanam secara mix cropping dengan tanaman lainnya, namun ada pula petani yang menanam secara monokultur dalam petak tetapi pada areal yang sama. Salah satu ciri lahan pertanian masyarakat suku Arfak baik pada perladangan berpindah dan usahatani menetap adalah terdapatnya tanaman ubi jalar dan talas/keladi. Hal ini disebabkan ubi-ubian selain sebagai makanan pokok, juga berfungsi sebagai pakan ternak babi. 
Umi Yuminarti, Dwidjono Hadi Darwanto, Jamhari, Subejo -- Studi Komparasi Praktik Perladangan Berpindah dan Pertanian Menetap untuk Mendukung Ketahanan Pangan Masyarakat (Studi pada Usahatani Kentang di

Kabupaten Pegunungan Arfak, Provinsi Papua Barat)

Tabel 11

Sebaran Produksi Kentang Per Musim Petani Perladangan Berpindah Dan Usahatani Menetap Di Kabupaten Pegunungan Arfak

\begin{tabular}{lcccc}
\hline Produksi (kg) & Ladang Berpindah (orang) & Persentase (\%) & Usahatani Menetap (orang) & Persentase (\%) \\
\hline$<100$ & 1 & 1,96 & 1 & 1,89 \\
$100-300$ & 22 & 43,14 & 32 & 60,38 \\
$>300-500$ & 27 & 52,94 & 20 & 37,74 \\
$>500$ & 1 & 1,96 & 0 & 0 \\
\hline Jumlah & 51 & 100,00 & 53 & 100,00 \\
\hline
\end{tabular}

Sumber : Data primer, 2017

Cara menanam kentang yang sering dilakukan petani sangat bervariasi, yaitu dalam larik secara teratur maupun tidak teratur, secara berkelompok untuk satu jenis tanaman yang sama atau dengan sistem tumpangsari antara dua jenis tanaman. Bagi petani di daerah yang lahannya terbatas, pola tumpangsari kentang dengan tanaman lain sangat tepat jika tujuannya untuk memaksimalkan pemanfaatan lahan. Namun petani suku Arfak yang memiliki lahan cukup luas pola tanam tumpang sari dilakukan ini dengan alasan menyediakan bahan pangan dalam satu areal agar mudah diakses untuk memenuhi kebutuhan hidup maupun untuk dijual.

Hasil produksi kentang saat ini rendah, namun demikian petani masih dapat memanfaatkan produksi sebagian besar untuk dijual selain untuk konsumsi, bahkan digunakan sebagai persediaan bibit pada pertanaman berikutnya. Hal ini menggambarkan bahwa sebagai petani tradisional, petani di Kabupaten Pegunungan Arfak dalam memproduksi usahatani selalu menyesuaikan dengan kebutuhannya pada saat ini, belum berfikir untuk masa depan. Artinya petani belum berfikir seperti petani modern yang dalam melakukan usahatani telah berorientasi komersial dan berfikir usahatani dilakukan saat ini demi kehidupan dimasa depannya. Jumlah produksi kentang disajikan pada tabel 11.
Produksi kentang perladangan berpindah per musim rata-rata sebanyak $296,08 \mathrm{~kg}$. Pada tabel 11 ditunjukkan bahwa sebagian besar petani memproduksi kentang lebih dari $100-500 \mathrm{~kg} /$ musim. Pada usahatani menetap sebagian besar petani $(52,94 \%)$ memproduksi kentang pada kisaran lebih dari 300-500kg per musim, sementara pada usahatani menetap sebagian besar petani $(60,38 \%)$ memproduksi kentang pada kisaran 100-300kg per musim. Hal ini disebabkan luas lahan pada usahatani menetap terbatas akibat wilayah usahatani menetap telah banyak digunakan sebagai kawasan permukiman setelah perkembangan wilayah menjadi sebuah pusat pemerintahan kabupaten. Masalah yang dihadapi petani dalam usahatani adalah pemasaran hasil, yang disebabkan karena jarak lokasi produksi dan pasar di Kota Manokwari jauh, sedangkan sarana dan prasarana transportasi terbatas sehingga biaya pemasaran menjadi mahal.

Produksi kentang petani pada usahatani menetap per musim rata-rata 283,77 $\mathrm{kg}$, dengan demikian produksi kentang perladangan berpindah lebih tinggi dari pada produksi kentang pada usahatani menetap. Namun dengan rata-rata luas lahan perladangan berpindah 0,146 ha dan luas lahan pada usahatani menetap 0,057 ha, maka produktivitas lahan usahatani menetap lebih tingi dari pada perladangan berpindah. Produktivitas lahan perladangan berpindah 
sebanyak 2,027 ton/ha, sedangkan usahatani menetap sebanyak 4,997 ton/ha.

\section{Praktik Perladangan Berpindah dan Usahatani Menetap.}

Sistem perladangan berpindah maupun usahatani menetap merupakan salah satu teknologi pertanian dalam perkembangan sejarah budidaya pertanian oleh manusia. Teknologi pertanian secara luas mencakup berbagai penerapan ilmu yang terfokus pada budidaya, pemeliharaan, pemanenan, peningkatan mutu hasil panen, penanganan, pengelolaan dan penyimpanan hasil dan pemasaran.

Sistem perladangan berpindah dapat dilakukan pada suatu wilayah jika, tingkat kepadatan penduduk suatu wilayah rendah. Dengan tingkat kepadatan penduduk di Kabupaten Pegunungan Arfak sebesar 10,19 jiwa/km2, masih memungkinkan sistem ini dapat dilakukan. Setelah terbentuk Kabupaten Pegunungan Arfak, dan wilayah di ibu kota kabupaten banyak terjadi konversi lahan untuk permukiman dan perkantoran maka petani sebagian besar memilih melakukan pertanian secara menetap. Namun cara bertani pada kedua sistem tidak banyak mengalami perubahan.

Pada tahap awal usahatani perladangan berpindah, diperlukan pengelolaan lahan, yaitu

Gambar 3a

Kebun Kentang Perladangan Berpindah

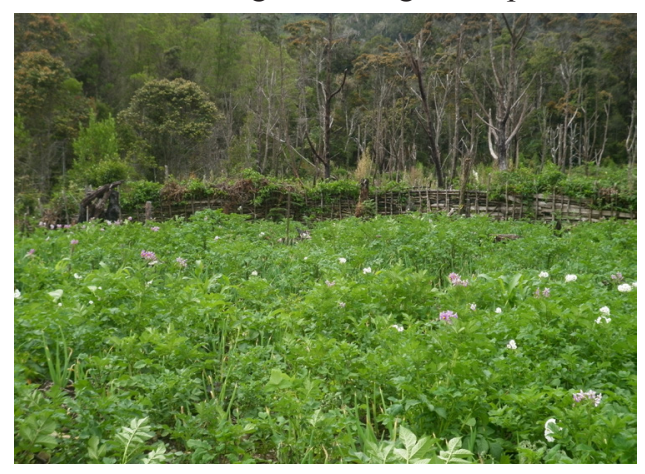

Sumber : Dokumentasi Peneliti, 2017 membuka lahan dengan cara menebang pohonpohon, selanjutnya dibiarkan untuk beberapa waktu (kurang lebih 1-2 minggu) hingga dahan-dahan kering kemudian dilakukan pembakaran. Pada saat membersihkan rantingranting sisa hasil pembakaran, kegiatan pemagaran dilakukan dengan menggunakan kayu dari hasil penebangan pohon dan rotan sebagai pengikat. Pemagaran lahan dilakukan untuk menghindari hama perusak tanaman terutama babi hutan, Persiapan lahan usahatani perladangan berpindah seperti pada gambar 2 .

Gambar 2

Lahan Usahatani Perladangan Berpindah

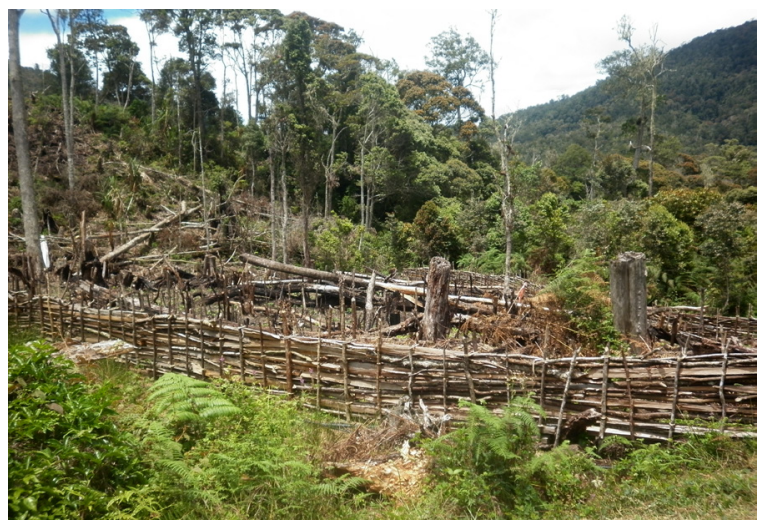

Sumber : Dokumentasi Peneliti, 2017

Pada usahatani menetap kegiatan awal yang membedakan dengan perladangan berpindah adalah tidak dilakukan kegiatan

Gambar 3b
Kebun Kentang Usahatani Menetap

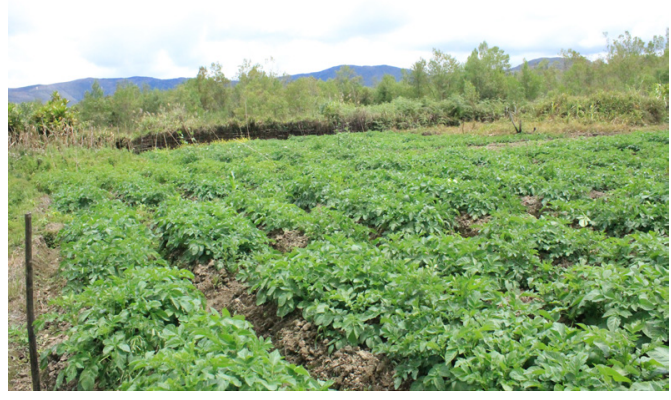

Sumber : Dokumentasi Peneliti, 2017 
Umi Yuminarti, Dwidjono Hadi Darwanto, Jamhari, Subejo -- Studi Komparasi Praktik Perladangan Berpindah dan Pertanian Menetap untuk Mendukung Ketahanan Pangan Masyarakat (Studi pada Usahatani Kentang di

Kabupaten Pegunungan Arfak, Provinsi Papua Barat)

Tabel 12

Tahapan Usahatani Kentang Secara Perladangan Berpindah Dan Usahatani Menetap

Di Kabupaten Pegunungan Arfak.

\begin{tabular}{|c|c|c|}
\hline \multirow{2}{*}{$\begin{array}{c}\text { Tahapan } \\
\text { Kegiatan }\end{array}$} & \multicolumn{2}{|c|}{ Uraian Kegiatan } \\
\hline & Perladangan Berpindah & Usahatani Menetap \\
\hline Persiapan & $\begin{array}{l}\text { Pembukaan Lahan dengan cara: } \\
\text { - Menebang Pohon } \\
\text { - Membakar ranting yang kering } \\
\text { - Membersihkan } \\
\text { - Membuat Pagar dari cabang atau pohon dan } \\
\text { diikat dengan rotan }\end{array}$ & $\begin{array}{l}\text { Persiapan kebun } \\
\text { - Membersihkan kembali } \\
\text { lahan usaha. } \\
\text { - Membakar rumput dan } \\
\text { semak yang telah dicabut } \\
\text { - Pembuatan pagar situasional jika ada hama } \\
\text { pengganggu tanaman (babi) }\end{array}$ \\
\hline Penanaman & $\begin{array}{l}\text { - Bibit tanaman sebagian besar berasal dari } \\
\text { tanaman hasil panen. } \\
\text { - Apabila tidak memiliki bibit petani membeli } \\
\text { atau dari keluarga. } \\
\text { - Jarak tanam } 20 \times 20 \mathrm{~cm} \text { s/d 30x30cm, bahkan } \\
\text { kadang ditanam secara acak } \\
\text { - Pola tanam; monokultur atau polikultur } \\
\text { secara acak dengan ubi jalar, buncis dan } \\
\text { sawi. }\end{array}$ & $\begin{array}{l}\text { - Bibit tanaman sebagian besar berasal dari } \\
\text { hasil panen. } \\
\text { - Apabila tidak memiliki bibit petani membeli } \\
\text { atau meminta dari keluarga. } \\
\text { - Jarak tanam 20x20m s/d 30x30cm. } \\
\text { - Pola tanam; monokultur, polikultur dengan } \\
\text { daun bawang }\end{array}$ \\
\hline Pemeliharaan & $\begin{array}{l}\text { - Pemeliharaan umumnya dilakukan oleh } \\
\text { tenaga kerja perempuan. } \\
\text { - Penyiangan dilakukan pada awal masa tanam } \\
\text { - Pupuk dan obat-obatan belum digunakan }\end{array}$ & $\begin{array}{l}\text { - Pemeliharaan umumnya dilakukan oleh } \\
\text { tenaga kerja perempuan. } \\
\text { - Penyiangan dilakukan 2-3 kali setiap minggu } \\
\text { - Pupuk dan obat-obatan belum digunakan }\end{array}$ \\
\hline Pemanenan & $\begin{array}{l}\text { - Dilakukan secara bertahap sesuai dengan } \\
\text { kebutuhan. } \\
\text { - Hasil yang akan dijual dibersihkan lebih } \\
\text { dahulu. } \\
\text { - Penyimpanan jarang dilakukan. } \\
\text { - Hasil sebagian disisihkan untuk bibit yang } \\
\text { disimpan dalam noken. }\end{array}$ & $\begin{array}{l}\text { - Dilakukan serentak, dan dibersihkan. } \\
\text { - Penyimpanan hanya sementara waktu, untuk } \\
\text { selanjutnya sebagian besar dijual. } \\
\text { - Hasil sebagian disisihkan untuk bibit disimpan } \\
\text { dalam noken. }\end{array}$ \\
\hline
\end{tabular}

Sumber : Data primer, 2016

penebangan pohon dan pembakaran lahan secara luas, dalam arti pembakaran dilakukan pada bekas kebun yang telah dibersihkan. Kegiatan pemagaran hanya dilakukan pada beberapa lokasi kebun yang dianggap kurang aman dari babi hutan. Kondisi usahatani perladangan berpindah dan usahatani menetap disajikan pada gambar $3 a$ dan $3 b$.

Pada saat ini dengan dikenalnya teknologi alat, petani perladangan berpindah menebang pohon bukan hanya menggunakan kapak, tetapi telah menggunakan Chain shaw dengan cara sewa atau meminjam. Sedangkan untuk membersihkan lahan digunakan alat sederhana berupa kapak dan parang. Pengolahan lahan tidak dilakukan oleh petani setelah pembakaran. Abu sisa hasil pembakaran dibiarkan kurang lebih 1 minggu agar menambah unsur hara dalam tanah, sebelum lahan siap digunakan.

Pada perladangan berpindah pembukaan kebun baru dilakukan sebelum kebun lama selesai dipanen, yaitu dengan cara membuka lahan yang telah lama ditinggalkan. Lahan yang ditinggalkan untuk masa bera yang lama berfungsi untuk menyuburkan lahan. Berdasarkan hasil wawancara, diperoleh informasi bahwa lama bera lahan pada perladangan berpindah antara 3 tahun hingga mencapai 15 tahun. Semakin lama masa bera lahan memberi manfaat bagi pertumbuhan 
tanaman, sehingga produksi akan semakin tinggi. Bagi petani pada pertanian menetap, pemanfaatan lahan secara terus menerus tanpa menggunakan pupuk, berakibat menurunkan tingkat kesuburan tanah dengan cepat. Namun demikian petani di Pegunungan Arfak memiliki pengetahuan lokal untuk menyuburkan lahannya, yaitu dengan cara membakar sisa semak dan rumput pada lahan setelah melakukan panen. Abu hasil pembakaran yang dibiarkan dalam jangka waktu tertentu menjadi pupuk untuk membantu menyuburkan kembali tanah. Tahapan usahatani kentang disajikan pada tabel 12

Pada umumna saat kegiatan pembukaan lahan, pemilik lahan dibantu keluarga besar dalam satu klan, selanjutnya pemilik akan membagi areal lahan yang telah dibuka sebagai kebun bersama dengan beberapa keluarga yang membantu. Pada usahatani menetap kegiatan membersihkan kebun dilakukan oleh keluarga inti, walaupun demikian jika luasan lahan cukup besar kegiatan ini dilakukan dengan bantuan anggota dari kelompok marga yang sama. Penyediaan bibit tanaman kentang berasal dari hasil panen baik pada perladangan berpindah dan usahatani menetap sama, yaitu dengan cara menyimpan dalam noken

Gambar 4

Penyimpanan Kentang Dalam Noken Untuk Bibit

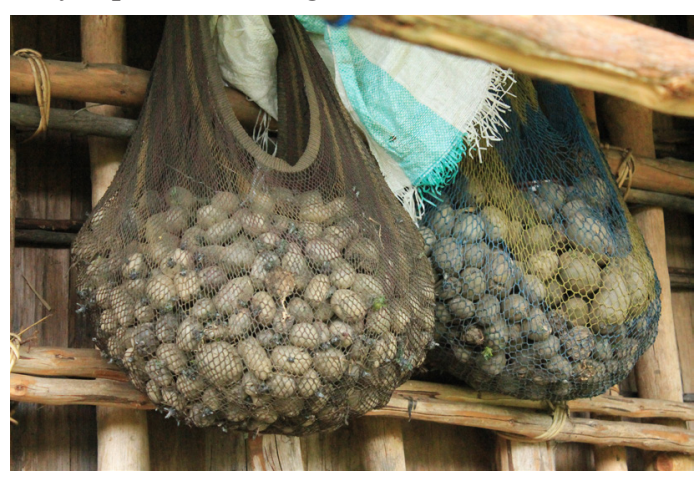

Sumber : Dokumentasi Peneliti, 2017 selama 3 bulan atau hingga menunggu siap tanam. Cara penyimpanan hasil panen untuk bibit disajikan pada gambar 4 .

Petani di Kabupaten Pegunungan Arfak sebagian besar menggunakan bibit kentang berasal dari hasil panen, karena bibit kentang hasil panen dianggap lebih baik daripada bibit kentang yang berasal dari luar Pegunungan Arfak. Keadaan ini perlu menjadi perhatian pemerintah daerah Kabupaten Pegunungan Arfak, karena untuk mendapatkan produksi dan produktivitas tinggi bibit sebaiknya menggunakan bibit bersertifikasi sebagai inovasi bagi petani. Walaupun untuk merubah perilaku petani untuk beralih dari pertanian tradisional dengan menggunakan inovasi agak sulit, namun melalui penyuluhan dengan menggerakkan petani-petani muda tantangan tersebut secara perlahan diharapkan dapat diatasi. Selain itu hal penting berkaitan dengan harga kentang adalah ketika produksi tinggi harga kentang ternyata tidak terpengaruh, artinya harga tetap, bahkan yang sering terjadi untuk produk kentang lokal harga meningkat, sehingga tidak menurunkan minat petani berusahatani dan memproduksi kentang. Hal ini berbeda dengan pendapat Jaya (2018), yang menyatakan ketika harga komoditas pertanian naik pemerintah cenderung tidak suka dan berusaha menurunkan harga komoditas pertanian secara cepat, sehingga petani enggan untuk menjadi petani atau bekerja di sektor pertanian. Keadaan ini menyebabkan keinginan berusahatani rumah tangga petani mengalami penurunan dan dapat melemahkan ketahanan pangan suatu wilayah. Pada usahatani kentang di Kabupaten Pegunungan Arfak, penurunan minat petani bukan akibat harga kentang 
Umi Yuminarti, Dwidjono Hadi Darwanto, Jamhari, Subejo -- Studi Komparasi Praktik Perladangan Berpindah dan Pertanian Menetap untuk Mendukung Ketahanan Pangan Masyarakat (Studi pada Usahatani Kentang di

Kabupaten Pegunungan Arfak, Provinsi Papua Barat)

Tabel 13

Produksi, Produktivitas, Biaya Usahatani Dan Pendapatan Petani Kentang Di Kabupaten Pegunungan Arfak

\begin{tabular}{lrrrrrr}
\hline \multirow{2}{*}{ Variabel } & \multicolumn{2}{c}{ Nilai Pada Perladangan Berpindah } & \multicolumn{3}{c}{ Nilai Pada Usahatani Menetap } \\
\cline { 2 - 7 } & Minimum & Maksimum & Rata-rata & Minimum & Maksimum & Rata-rata \\
\hline Produksi (kg) & 80,00 & 550,00 & 296,08 & 80,00 & 500,00 & 280,94 \\
Produktivitas (ton/ha) & 0,72 & 6,67 & 2,42 & 2,50 & 21,00 & 5,79 \\
Penerimaan (Rp) & 1.600 .000 & 9.900 .000 & 5.792 .549 & 1.500 .000 & 9.000 .000 & 5.285 .471 \\
Biaya Usahatani (Rp) & 644.875 & 3.249 .167 & 1.583 .989 & 513.125 & 2.022 .960 & 1.258 .050 \\
Pendapatan (Rp) & 696.300 & 8.057 .700 & 4.208 .560 & 867.500 & 7.376 .375 & 4.027 .421 \\
\hline
\end{tabular}

Sumber : Analisis Data Primer, 2017

turun, karena kentang merupakan tanaman hortikultura sehingga harga relatif stabil.

\section{Perbandingan Produktivitas dan Pendapatan Usahatani Kentang Perladangan Berpindah dan Usahatani Menetap}

Usahatani perladangan berpindah bagi petani suku Arfak merupakan suatu cara berusahatani yang telah dilakukan sejak dahulu. Hal ini dilakukan karena pengetahuan petani tentang teknologi budidaya masih terbatas. Salah satu cara yang dilakukan petani untuk memperoleh produksi tinggi pada sistem pertanian ini adalah berusaha mencari dan mengolah lahan yang subur dengan membuka lahan baru. Adanya perubahan dalam perkembangan administrasi pemerintahan di wilayah Pegunungan Arfak menyebabkan beberapa kampung di sekitar pusat pemerintahan Kabupaten Pegunungan Arfak memiliki lahan terbatas untuk usahatani sistem perladangan berpindah, sehingga secara perlahan petani mulai menerapkan usahatani menetap. Perubahan ini menimbulkan perbedaan pendapatan dan produktivitas maupun efisiensi produksi pada kedua sistem usahatani kentang. Menurut Subekti, dkk (2016) pendapatan merupakan salah satu ukuran kesejahteraan masyarakat yang menjadi bagian dari ketahanan ekonomi. Dengan adanya ketahanan ekonomi keluarga mempengaruhi ketahanan pangan keluarga, sebagai pembentuk ketahanan pangan masyarakat. Deskripsi nilai variabel produksi, produktivitas, biaya usahatani dan pendapatan petani kentang perladangan berpindah dan usahatani menetap disajikan pada tabel 13.

Pada tabel 13 ditunjukkan bahwa ratarata produktivitas kentang perladangan berpindah lebih rendah dibandingkan usahatani menetap. Walaupun produktivitas kentang pada dua wilayah studi ini lebih tinggi jika dibanding dengan rata-rata produktivitas kentang secara keseluruhan di Papua Barat (1,26 ton/ha), tetapi masih sangat rendah jika dibanding dengan rata-rata tingkat nasional (14,37 ton/ha). Produktivitas lahan untuk tanaman kentang pada perladangan berpindah lebih rendah, namun rata-rata pendapatan lebih tinggi, disebabkan lahan usaha pada perladangan berpindah lebih luas, selain itu faktor lama bera pada perladangan berpindah sebagai faktor penting dalam menyuburkan tanah, sehingga rata-rata produksi kentang pada perladangan berpindah cenderung lebih tinggi dibanding usahatani menetap.

Produksi dan produktivitas usahatani kentang di Kabupaten Pegunungan Arfak rendah, sebagai akibat menurunnya minat petani bekerja pada sektor pertanian dan berubahnya pola konsumsi masyarakat. Adanya program Raskin diduga sebagai 
salah satu faktor penyebab berubahnya pola konsumsi. Dengan sifat petani tradisional dalam berusahatani pada umumnya yang terpenting cukup untuk memenuhi kebutuhan keluarga dan apabila ada sisa dijual menyebabkan tidak adanya usaha untuk menanam kentang dalam jumlah banyak. Selain itu petani memiliki sifat takut dengan risiko jika menanam dalam jumlah besar dan sulit memasarkan akan mengakibatkan kerugian. Pola konsumsi dan sifat-sifat petani serta program pemerintah demikian yang justru menjadi menghambat peningkatan produksi kentang, walaupun wilayah Kabupaten Pegunungan Arfak merupakan wilayah potensial untuk usahatani kentang, yang jika ditangani dengan serius merupakan sumber pendapatan utama bagi petani.

Kelebihan sistem perladangan berpindah dibandingkan dengan usahatani secara menetap bagi petani tradisional yang memiliki teknologi terbatas adalah mendapatkan lahan yang subur sehingga jumlah dan kualitas produksi kentang sesuai dengan harapan petani. Produktivitas lahan pada perladangan berpindah menunjukkan hasil berbeda, karena petani pada usahatani menetap akan berusaha untuk memperoleh produksi yang tinggi dengan lahan yang lebih terbatas, sehingga produktivitas usahatani menetap lebih tinggi dibanding perladangan berpindah. Analisis perbandingan produktivitas, dan pendapatan usahatani kentang per musim pada perladangan berpindah dan pertanian menetap disajikan pada tabel 14 .

Hasil analisis pada tabel 14 menunjukkan bahwa rata-rata produktivitas pada perladangan berpindah lebih rendah dibanding dengan usahatani menetap. Namun rata-rata pendapatan perladangan berpindah lebih tinggi dari pada usahatani menetap.

Perbedaan rata-rata produktivitas antara usahatani perladangan berpindah dan menetap cukup besar. Berdasarkan hasil uji t beda ratarata produktivitas usahatani menetap lebih besar daripada perladangan berpindah, hal ini dapat dijelaskan bahwa pada usahatani menetap petani berusaha memaksimalkan penggunaan lahannya dengan pengaturan jarak tanam. Rata-rata jarak tanam yang digunakan petani dengan pola tanam monokultur pada kisaran $20 \mathrm{~cm}$ x $20 \mathrm{~cm}$ sampai $20 \mathrm{~cm}$ x $30 \mathrm{~cm}$, sedangkan untuk pola campuran jarak tanam antar tanaman kentang seperti pada pola monokultur atau bahkan terdapat jarak tanam lebih lebar hingga $40 \mathrm{~cm} \times 50 \mathrm{~cm}$. Tanaman lainnya yang ditanam pada area yang sama pada pola monokultur dan campuran adalah sawi, buncis, jagung dan ubi jalar yang ditanam secara bertahap.

Pendapatan per musim dari hasil usahatani kentang pada perladangan berpindah dan usahatani menetap terdapat selisih yang

Tabel 14

Analisis Perbandingan Produktivitas, Pendapatan Kentang Perladangan Berpindah Dan Usahatani Menetap

\begin{tabular}{|c|c|c|c|c|c|}
\hline \multirow{2}{*}{ Variabel } & \multicolumn{2}{|c|}{ Ladangan Berpindah $(\mathrm{N}=51)$} & \multicolumn{2}{|c|}{ Usahatani Menetap $(\mathrm{N}=53)$} & \multirow{2}{*}{ t-hitung } \\
\hline & Rata-rata & Std.Deviasi & Rata-rata & Std.Deviasi & \\
\hline Produktivitas (ton/ha) & 2,42 & 1,37 & 5,79 & 2,82 & $7,768 * * *$ \\
\hline Pendapatan (Rp) & $4.208 .560,26$ & $1.862 .797,42$ & $4.027 .421,32$ & $1.627 .089,01$ & $-0,527 \mathrm{~ns}$ \\
\hline
\end{tabular}

Sumber : Analisis Data Primer, 2017

Keterangan:

$* * * \quad$ : Signifikan pada $\alpha=1 \% ; \mathrm{t}_{\text {tabel } 0,01 ; 102}=2,6248$

ns : Tidak Signifikan 
Umi Yuminarti, Dwidjono Hadi Darwanto, Jamhari, Subejo -- Studi Komparasi Praktik Perladangan Berpindah dan Pertanian Menetap untuk Mendukung Ketahanan Pangan Masyarakat (Studi pada Usahatani Kentang di Kabupaten Pegunungan Arfak, Provinsi Papua Barat)

kecil, perbedaan tersebut disebabkan luas tanam kentang pada perladangan berpindah relatif lebih besar, sehingga produksi lebih banyak, dan berpengaruh terhadap pendapatan petani. Hasil uji t beda rata-rata pendapatan menunjukkan bahwa tidak terdapat perbedaaan pendapatan antara usahatani menetap dan perladangan berpindah.

Produksi kentang ditentukan oleh curahan kerja pada masing-masing usahatani. Rata-rata curahan kerja pada ladang berpindah sebesar 33,085 HOK, sedangkan pada usahatani menetap sebesar 22,027 HOK. Penggunaan tenaga kerja dalam usahatani berhubungan dengan banyaknya kegiatan yang dilakukan petani di luar usahatani pada lokasi studi maupun di luar lokasi studi. Petani pada usahatani menetap memiliki tingkat pendidikan rata-rata 6,75 tahun atau setara dengan kelas 1 SMP atau lebih tinggi dibanding petani pada perladangan berpindah. Keadaan ini menyebabkan petani lebih tertarik bekerja sebagai tenaga honorer pada Pemerintah Daerah. Sedangkan petani pada perladangan berpindah berpendidikan rata-rata 3,22 tahun (3 SD), sehingga kegiatan utamanya bertani dan berburu, karena tingkat pendidikan rendah menyebabkan petani tidak memiliki kesempatan bekerja di luar sektor pertanian.

\section{Mendukung Ketahanan Pangan Masyarakat}

Produksi kentang yang dihasilkan petani ladang berpindah maupun pertanian menetap di Kabupaten Pegunungan Arfak selain dikonsumsi juga dijual. Persentase produksi kentang yang dijual pada saat ini menunjukkan peningkatan dibanding pada waktu sebelum ada program pemerintah (Raskin), hal ini menunjukkan bahwa Raskin berpengaruh terhadap perubahan pola konsumsi masyarakat.
Keadaan yang sama terjadi pada petani yang menerapkan usahatani menetap, dimana hasil panen kentang saat ini sebagian besar dijual.

Berdasarkan uraian di atas diketahui bahwa produksi kentang di Kabupaten Pegunungan Arfak beberapa tahun ini terus mengalami penurunan. Hal ini disebabkan petani dalam berusahatani belum sepenuhnya berorientasi ekonomi, artinya usahatani yang dilakukan semata-mata hanya untuk memenuhi kebutuhan keluarga walaupun hasilnya sebagian dijual namun persentase hasil penjualan produk kentang dan juga hasil pertanian lainnya untuk kebutuhan konsumsi keluarga, sehingga dengan adanya program Raskin petani merasa sebagian beban untuk memenuhi kebutuhan bahan pangan pokok bagi keluarga telah dibantu pemerintah, sehingga merasa tidak perlu bekerja lebih keras untuk menyediakan kebutuhan pangannya. Pemanfaatan produksi dan kontribusi pendapatan petani dari usahatani kentang perladangan berpindah dan usahatani menetap untuk memenuhi kebutuhan pangan disajikan pada gambar 5 .

Gambar 5

Rata-Rata Produksi Kentang Dan Alokasi Untuk DiJual Di Kabupaten Pegunungan Arfak

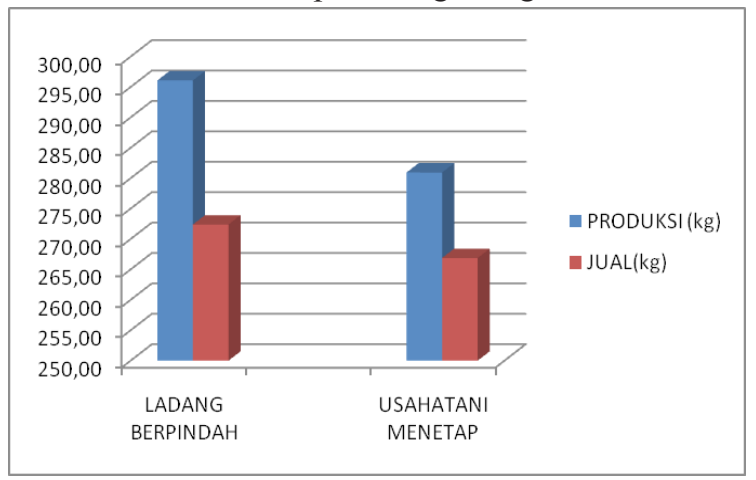

Sumber: Analisis Data Primer, 2017

Gambar 5 di atas menunjukkan bahwa dari jumlah produksi kentang yang dihasilkan 
petani, lebih kurang sebesar $92 \%$ produksinya dijual, sedangkan sisanya selain untuk dikonsumsi juga untuk bibit pada masa tanam selanjutnya. Proporsi pendapatan yang diperoleh dari penjualan kentang oleh petani sebagian besar digunakan untuk membeli kebutuhan pangannya, yaitu beras, minyak goreng, gula dan kopi. Sedangkan persentase pendapatan yang digunakan untuk kebutuhan non pangan sangat rendah.

Gambar 6

Rata-rata Pendapatan Dan Alokasi Untuk Bahan Pangan Di Kabupaten Pegunungan Arfak

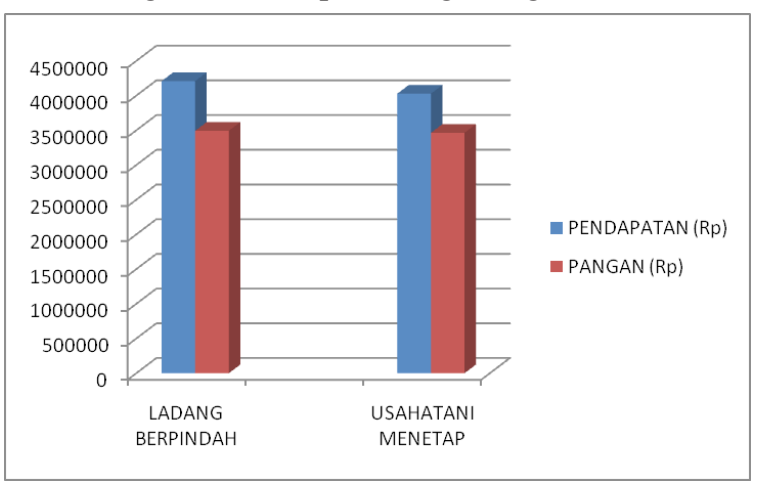

Sumber: Analaisis Data Primer, 2017

Gambar 6 di atas menunjukkan bahwa, persentase pendapatan dari usahatani kentang sebagian besar digunakan untuk membeli bahan pangan pokok. Menurut Teori Engel, semakin membaiknya pendapatan keluarga biasanya akan diiringi dengan alokasi pengeluaran untuk kebutuhan pangan yang cenderung menurun. Namun jika proporsi pengeluaran lebih besar untuk konsumsi pangan mengindikasikan bahwa keluarga tersebut berpenghasilan rendah, sehingga petani di Kabupaten Pegunungan Arfak masih tergolong dalam keluarga dengan penghasilan rendah. Namun demikian kepemilikan lahan adat merupakan modal penyedia bahan pangan seperti ubi-ubian dan kentang sebagai sumber karbohidrat, serta tanaman hortikultura sebagai sumber vitamin. Pendapatan bagi petani masih dirasakan sebagai pelengkap dalam memenuhi kebutuhan sehari-hari. Kondisi ini menunjukkan bahwa praktik perladangan berpindah dan usahatani menetap berkontribusi dalam mendukung ketahanan pangan masyarakat di Kabupaten Pegunungan Arfak.

\section{SIMPULAN}

Berdasarkan pembahasan di atas maka dapat ditarik simpulan sebagai berikut.

Pertama, petani di Kabupaten Pegunungan Arfak sebagai petani tradisional melakukan praktik usahatani perladangan berpindah, namun saat ini telah melakukan pertanian secara menetap. Teknologi yang digunakan pada kedua praktik usahatani masih dilakukan secara tradisional, sehingga untuk meningkatkan teknologi petani diperlukan penyuluhan terutama kepada petani usia muda agar teknologi cepat diterima dan diterapkan.

Kedua, produksi dan pendapatan petani perladangan berpindah lebih tinggi dibanding petani pada pertanian menetap, namun produktivitas pertanian menetap lebih tinggi dibanding perladangan berpindah. Produktivitas dapat ditingkatkan dengan mengelola lahan lebih efisien, yaitu dengan pengaturan jarak tanam sesuai rekomendasi instansi terkait, menggunakan benih bermutu dan menjaga lingkungan wilayah pegunungan Arfak.

Ketiga, hasil produksi kentang perladangan berpindah dan usahatani menetap dimanfaatkan untuk dikonsumsi maupun dijual. Namun sebagian besar yang dijual hasilnya digunakan kembali untuk membeli bahan pangan untuk konsumsi keluarga. Dengan demikian kebutuhan pangan keluarga terpenuhi sebagai ukuran ketahanan pangan masyarakat dari hasil 
Umi Yuminarti, Dwidjono Hadi Darwanto, Jamhari, Subejo -- Studi Komparasi Praktik Perladangan Berpindah dan Pertanian Menetap untuk Mendukung Ketahanan Pangan Masyarakat (Studi pada Usahatani Kentang di Kabupaten Pegunungan Arfak, Provinsi Papua Barat)

praktek usahatani padang berpindah dan pertanian menetap.

Keempat, produksi kentang yang cenderung menurun disebabkan minat berusahatani masyarakat menurun, karena beberapa alasan antara lain (1). Perubahan pola makan dari ubi-ubian ke nasi, akibat dikenalnya beras dari program Raskin. (2). Sifat petani tradisional yang berusahatani hanya menyesuaikan kebutuhan sesaat petani dan keluarganya, karena belum berorientasi komersiil, sehingga usahatani kentang yang secara turun temurun dilakukan hanya sebatas untuk memenuhi kebutuhan pangan. (3). Petani yang memiliki pendidikan lebih memilih bekerja sebagai staf honorer pada instansi yang ada setelah wilayah ini terbentuk sebagai kabupaten baru. Dengan demikian walaupun wilayah ini sangat berpotensi untuk pengembangan usahatani kentang namun potensi ini belum dimanfaatkan sepenuhnya baik oleh petani dan pemerintah daerah. Oleh karena itu peran pemerintah daerah bersama-sama dengan Lembaga Swadaya Masyarakat dan perguruan tinggi diperlukan untuk merubah pola pikir dan meningkatkan minat petani dalam memproduksi kentang, baik melalui tindakan nyata dengan pendampingan kepada petani maupun melalui kebijakan pemerintah terkait dengan ketahanan pangan di Kabupaten Pegunungan Arfak.

\section{DAFTAR PUSTAKA}

Anderson, J.R, and W.E. Griffiths. 1982. Production Risk and Efficient Allocation of Resources. Australian Journal of Agricultural Economics. Vol 2. No.3, Desember 1982.

Arifin, Bustanul. 2005. Pembangunan Pertanian: Paradigma Kebijakan dan Strategi Revitalisasi. Jakarta:Penerbit PT Grasindo.
Beattie R. And C. Robert Taylor. 1985. The Economics of Production (Ekonomi Produksi, alih bahasa: Soeratno). Yogyakarta: Gadjah Mada University Press.

Boediono. 1997. Ekonomi Moneter dan Internasional, . Yogyakarta :BPFE.

BPS Provinsi Papua Barat, 2014. Papua Barat Dalam Angka 2014. Manokwari: Badan Pusat Statistik Provinsi Papua Barat..

--------, 2016. Papua Barat Dalam Angka 2016. . Manokwari:Badan Pusat Statistik Provinsi Papua Barat

Brown, M.L. 1979. Farm Budgets from Farm Income Analysis to Agricultural Project Analysis. . Baltimore and London: Published for the World Bank. The Johns Hopkins University Press.

Crammer, G.L.\& C.W. Jensen. 1994. Agricultural Economics and Agribusiness: Sixth Edition, John Wiley and Sons, Inc. New York.

Darwanto D.H., 2005. Ketahanan Pangan Berbasis Produksi dan Kesejahteraan Petani. Ilmu Pertanian. Vol. 12, No.2, hh. $152-164$.

Dewan Ketahanan Pangan, 2009. Panduan Penyusunan Petan Ketahanan dan Kerentanan Pangan di Indonesia; A Foof Security and Vulnerability Atlas of Indonesia (FSVA). Jakarta: Dewan Ketahanan Pangan dan World Food Programme.

Hakim, M.A., 2014. Memperkuat Ketahanan Pangan Demi Masa Depan Indonesia 2015-2025. , Jakarta: CV. Rumah Buku

Houghton,R.A, Lefkowitz,D.S, Scole,D.L. 1991. Change in The Landscape of Latin America Between 1850 and 1885. I. progressive Loss of Forest. Forests 
Ecology and Management. Vol.38, no. 3-4. hh.143-172.

Jamison, D. T.\& L. J. Lau. 1982. Farmer Education and Farm Efficiency. A World Bank Research Publication. The Johns Hopkins University Press. Baltimore.

Jong, W., M. Sirait, N. Liswanti, 2001. Farming Secondary Forests in Indonesia. Journal of Tropical Forest Science 13 (4): 705-726

Jaya, Pajar Hatma Indra, 2018. Nasib Petani dan Ketahanan Pangan Wilayah (Studi Tentang Kebijakan Pemerintah dan Respons Masyarakat Desa Mulyodadi, Bantul Ketika Harga Komoditas Pertanian Naik), Jurnal Ketahanan Nasional, vol 24, no. 1, hh. 77-93.

Mubyarto, 1994. Pengantar Ekonomi Pertanian. Jakarta :LP3ES..

Nasir, M., 2005. Metodologi Penelitian. Ghalia Indonesia, Jakarta

Pindyck, R.S. \& D.L. Rubinfield, 2001. Microeconomics. Prentice Hall International, Inc. Canada.

Samuelson, P.A\& W.D. Nordhaus. 2001. Microeconomics. Seventeenth Edition. McGraw-Hill Irwin. Boston.

Serrao,E,A., Nepstad, D., Walker, R.T. Upland Agricultural and Forestry Development in
The Amazon: Sustainability, Criticality and Resilience. Ecological Economics. vol.18. no.1, hh.3-13.

Soeharjo dan Dahlan Patong, 1993. SendiSendi Pokok Usahatani. Institut Pertanian Bogor:Departemen Ilmu-Ilmu Sosial Ekonomi Fakultas Pertanian.

Soekartawi. 1986. Prinsip-prinsip Dasar Manajemen Hasil Pertanian, Teori dan Aplikasinya. Jakarta.: Radjawali Press.

Soekartawi, 2002. Prinsip Dasar Ekonomi Pertanian, Teori dan Aplikasi. Jakarta: PT. Raja Grafindo Persada.

Subekti Imam, Martono Edi, dan Hamid E.Suandi, (2016). Manajemen Koperasi Dalam Rangka Pengelolaan Hutan Rakyat dan Pengaruhnya Terhadap Ketahanan Ekonomi Masyarakat (Studi Pada Koperasi Wana Lestari Menoreh di Kabupaten Kulon Progo, DIY), Jurnal Ketahanan Nasional, vol 22, no. 2, hh. 158-179.

Todaro, Michael P. 1987. Pembangunan Ekonomi di Dunia Ketiga. Edisi Ketiga. Jakarta: Penerbit Erlangga.

\section{Peraturan Perundangan}

Undang-Undang Republik Indonesia, Nomor 7 Tahun 1996 Tentang Pangan 